\title{
PENJATUHAN PIDANA TERHADAP ANAK KORBAN PERKOSAAN INSES YANG MELAKUKAN ABORSI
}

\author{
Kajian Putusan Nomor 5/PID.SUS-ANAK/2018/PN.MBN
}

\section{CRIMINAL IMPOSITION AGAINST CHILDREN OF INCEST RAPE VICTIMS WHO DID AN ABORTION}

\author{
An Analysis of Decision Number 5/PID.SUS-ANAK/2018/PN.MBN
}

\author{
Mufidatul Ma'sumah \\ Fakultas Hukum Universitas Widyagama Malang \\ Jl. Taman Borobudur Indah No. 3 Malang 65142 \\ Email:mufida@widyagama.ac.id
}

\begin{abstract}
Naskah diterima: 4 Desember 2018; revisi: 26 Juli 2019; disetujui 19 Agustus 2019
http://dx.doi.org/10.29123/jy.v12i2.363
\end{abstract}

\begin{abstract}
ABSTRAK
Tulisan ini mengkaji tentang Putusan Nomor 5/PID. SUS-ANAK/2018/PN.MBN tanggal 19 Juli 2018, yang memidana seorang anak berumur 15 tahun di Jambi dengan vonis enam bulan penjara dan pelatihan kerja selama tiga bulan karena melakukan aborsi kehamilan hasil perkosaan kakak kandungnya (inses). Terkait dengan tindak pidana perkosaannya, kakak kandung telah diputus dengan pidana penjara dua tahun (Putusan Nomor 4/PID.SUS-ANAK/PN.MBN). Penelitian ini mempersoalkan apakah putusan hakim dengan memidana anak korban perkosaan inses yang melakukan aborsi sudah mempertimbangkan hak-hak anak sebagai korban. Penelitian hukum ini menggunakan metode yuridis normatif. Hasil dari penelitian diperoleh bahwa hakim tidak mempertimbangan hak-hak anak sebagai korban perkosaan inses. Pertimbangan putusan pidana oleh hakim adalah terdakwa telah memenuhi unsurunsur perbuatan pidana dan unsur-unsur kesalahan, serta tidak adanya alasan penghapus pidana, sehingga terdakwa dianggap mampu bertanggung jawab secara pidana dan selanjutnya dapat dipidana.
\end{abstract}

Kata kunci: aborsi, anak, korban perkosaan inses.

\section{ABSTRACT}

This paper analysis the judge's Decision Number 5/ PID.SUS-ANAK/2018/PN.MBN on July 19th, 2018 who convicted a 15-year-old child in Jambi with a sentence of six months in prison and job training for three months due to having an abortion of pregnancy that resulting from the rape of her biological brother (incest). Related to the crime of rape, the older sibling has been sentenced to two years in prison (Decision Number 4/PID.SUS$A N A K / P N . M B N)$. This research questions whether the judge's decision to convict the child of incest raped that had an abortion have considered the rights of children as victims. This legal research uses normative juridical methods. The results of the research obtained that the judge did not consider the rights of children as a victim of incest rape. The consideration of criminal decisions by the judge is the defendant has fulfilled the elements of a criminal offense and elements of error, as well as the absence of reasons for criminal offenses so that the defendant considered capable of being criminally responsible and subsequently convicted.

Keywords: abortion, children, incest rape victims. 


\section{PENDAHULUAN}

\section{A. Latar Belakang}

Masa anak-anak merupakan salah satu periode tumbuh kembang yang sangat berperan penting dalam kehidupan seorang anak. Perlindungan akan anak menjadi salah satu hal prioritas dalam kehidupan berbangsa dan bernegara Republik Indonesia, sehingga dituangkan dalam UUD NRI 1945 dan peraturan perundang-undangan lainnya. Pada kenyataannya perlindungan anak kian hari kian menunjukkan degradasinya. Modus-modus kejahatan yang menyerang anak kian mengalami peningkatan, khususnya terkait dengan pelecehan seksual.

Menurut Komisi Perlindungan Anak Indonesia, pada tahun 2011 saja telah terjadi 2.275 kasus kekerasan terhadap anak, 887 kasus di antaranya merupakan kekerasan seksual anak. Pada tahun 2012 kekerasan terhadap anak telah terjadi 3.871 kasus, 1.028 kasus di antaranya merupakan kekerasan seksual terhadap anak. Tahun 2013, dari 2.637 kekerasan terhadap anak, 48 persennya atau sekitar 1.266 merupakan kekerasan seksual pada anak (Noviana, 2015: 14).

Komisi Nasional Perempuan menyebutkan tahun 2017 kekerasan seksual terhadap perempuan ranah privat (inses) menempati posisi paling tinggi dibanding dengan bentuk kekerasan seksual lainnya. Sebanyak 1.210 terjadi kasus inses dengan rincian, 425 kasus dilakukan oleh ayah, 332 dilakukan paman, 89 kasus pelakunya adalah kakak, 58 kasus pelakunya kakek kandung, dan dilakukan oleh sepupu 44 kasus. Prosentase kasus kekerasan inses cukup tinggi, yakni 40,75\%. Setelah kasus inses urutan kedua ditempati kasus perkosaan (619 kasus), persetubuhan/eksploitasi seksual (555 kasus), pencabulan (379 kasus), marital rape (172 kasus), pelecehan seksual (32 kasus), kekerasan seksual lain (10 kasus), dan percobaan perkosaan (2 kasus) (CNN Indonesia, 2018).

Baru-baru ini publik dikejutkan dengan pemberitaan putusan Hakim Pengadilan Negeri Muara Bulian dengan Putusan Nomor 5/PID. SUS-ANAK/2018/PN.MBN yang memidana seorang anak 15 tahun, korban perkosaan dengan vonis enam bulan penjara dan pelatihan kerja selama tiga bulan, karena melakukan aborsi kehamilan hasil perkosaan yang dilakukan oleh kakak kandungnya sendiri. Pelaku perkosaan yang merupakan kakak kandung korban (inses) yang juga masih berusia anak dipidana dua tahun penjara (Putusan Nomor 4/PID.SUSANAK/2018/PN.MBN).

Putusan tersebut menimbulkan berbagai polemik di masyarakat, baik dalam tataran praktik sosiologis maupun dalam teoritis akademik. Dalam masyarakat menjadi preseden buruk bahwa anak yang dijatuhi pidana tersebut merupakan korban, tetapi kemudian justru dijatuhi pidana karena melakukan aborsi terhadap anak yang dikandungnya. Sahetapy mengemukakan kerugian-kerugian akibat suatu kejahatan yang diderita oleh korban kejahatan bukan hanya dalam bentuk fisik seperti biaya-biaya yang dikeluarkan untuk menyembuhkan luka fisik, tetapi juga kerugian non-fisik yang susah, bahkan tidak dapat dinilai dengan uang. Hilangnya keseimbangan jiwa, hilangnya semangat hidup, dan kepercayaan diri karena kecemasan dan ketakutan dari bayang-bayang kejahatan yang selalu terbayang menghantui, adalah salah satu dari sekian banyak kerugian non-fisik yang bisa timbul (Sahetapy, 1987: 36).

Dalam tataran akademis pun menimbulkan permasalahan, karena banyak sekali kekeliruan 
yang ada dalam putusan tersebut. Kekeliruan tersebut menurut kajian yang dilakukan oleh Institute for Criminal Justice Reform (ICJR) antara lain:

1. Pelanggaran hak atas bantuan hukum yang efektif dan kredibel. Berdasarkan Pasal 56 KUHAP dan berdasarkan Pasal 23 Undang-Undang Sistem Peradilan Pidana Anak, bantuan hukum untuk anak harus tersedia setiap dan bersifat wajib. Menurut informasi yang berhasil dihimpun oleh ICJR, penasihat hukum bagi anak dalam kedua perkara tersebut sama.

2. Penahanan terhadap anak korban perkosaan. Kedua terdakwa yang masih anak, termasuk anak korban perkosaan selama proses persidangan ditahan, korban perkosaan jelas membutuhkan perlindungan dari trauma perkosaan yang dialaminya.

3. Masa pemeriksaan yang singkat. Masa persidangan sangat singkat, tidak ada agenda sidang yang menjamin hak terpidana terlindungi. Agenda sidang hanya terdiri: 1) dakwaan; 2) pemeriksaan saksi dan anak; 3) tuntutan penuntut umum; dan 4) pembacaan putusan. Tidak ada agenda sidang pembelaan terdakwa. Padahal secara jelas dalam Konvenan Hak Sipil dan Politik, dan Hukum Acara Pidana yang diatur dalam KUHAP, setiap terdakwa berhak atas proses pemeriksaan yang adil.

4. Pelanggaran terhadap Peraturan Mahkamah Agung (PERMA) Nomor 3 Tahun 2017 tentang Pedoman Mengadili Perkara Perempuan Berhadapan dengan Hukum. Hakim dalam kedua perkara tersebut tidak memeriksa kasus secara hati-hati dengan tidak melihat secara holistik, bahwa terpidana untuk Putusan Nomor 5/PID. SUS-ANAK/2018/PN.MBN adalah korban perkosaan. Padahal berdasarkan PERMA tersebut, hakim dalam mengadili harus menggali rasa keadilan untuk menjamin kesetaraan gender, perlindungan yang setara, dan non-diskriminasi.

\section{B. Rumusan Masalah}

Berlandaskan pada latar belakang tersebut di atas, rumusan masalah mengenai kajian hukum dalam Putusan Nomor 5/PID.SUS-ANAK/2018/ PN.MBN adalah apakah putusan hakim dengan memidana anak korban perkosaan inses yang melakukan aborsi sudah mempertimbangkan hak-hak anak sebagai korban?

\section{Tujuan dan Kegunaan}

Adapun tujuan dari penulisan ini adalah untuk menganalisis putusan hakim, dengan memidana anak korban perkosaan inses yang melakukan aborsi, sudah mempertimbangkan hak-hak anak sebagai korban.

Kegunaan yang diharapkan dalam penulisan ini adalah dapat memberikan sumbangan pengetahuan di bidang hukum pidana, khususnya dalam memberikan penafsiran mengenai pertanggungjawaban pidana anak korban perkosaan inces.

\section{Tinjauan Pustaka}

1. Aborsi

Abortus yaitu keluarnya hasil pembuahan (janin) yang belum waktunya dari kandungan ibu dan belum dapat hidup di luar kandungan. Secara medis, aborsi adalah berakhirnya atau gugurnya kehamilan sebelum kandungan mencapai usia 20 
minggu atau berat bayi kurang dari 500 gram, yaitu sebelum janin dapat hidup di luar kandungan secara mandiri. Abortus adalah kehamilan yang berhenti prosesnya pada umur kehamilan di bawah 20 minggu, atau berat fetus yang lahir 500 gram atau kurang. Aborsi berarti terhentinya kehamilan yang terjadi di antara saat tertanamnya sel telur yang sudah (blastosit) di rahim sampai kehamilan 28 minggu. Abortus adalah keluarnya janin sebelum mencapai viabilitas, di mana masa gestasi belum mencapai 22 minggu dan beratnya kurang dari 500 gram (Ranoemihardja, 1991: 50).

Secara garis besar, abortus terbagi menjadi dua macam, yaitu abortus spontan dan abortus buatan. Abortus spontan adalah merupakan mekanisme alamiah yang menyebabkan terhentinya proses kehamilan sebelum berumur 28 minggu. Abortus buatan merupakan suatu upaya yang disengaja untuk menghentikan proses kehamilan sebelum berumur 28 minggu, di mana janin (hasil konsepsi) yang dikeluarkan tidak dapat bertahan hidup di dunia luar (Triwibowo, 2014: 167).

Ada beberapa istilah untuk menyebut keluarnya konsepsi atau pembuahan sebelum usia kehamilan 20 minggu yang biasa disebut aborsi (abortion), di antaranya: abortion criminalis yaitu pengguguran kandungan secara bertentangan dengan hukum; abortion eugenic yaitu pengguguran kandungan untuk mendapat keturunan yang baik; abortion induced/provoked/ provocatus yaitu pengguguran kandungan karena disengaja; abortion natural yaitu pengguguran kandungan secara alamiah; abortion spontaneous yaitu pengguguran kandungan secara tidak sengaja; dan abortion therapeutic yaitu pengguguran kandungan dengan tujuan untuk menjaga kesehatan sang ibu.

\section{Pertanggungjawaban Pidana}

Pertanggungjawaban pidana (criminal responsibility) adalah suatu mekanisme untuk menentukan apakah seseorang terdakwa atau tersangka dipertanggungjawabkan atas suatu tindakan pidana yang terjadi atau tidak. Saleh mengatakan bahwa dalam pengertian perbuatan pidana tidak termasuk hal pertanggungjawaban. Perbuatan pidana hanya menunjuk kepada dilarangnya perbuatan. Apakah orang yang telah melakukan perbuatan itu kemudian juga dipidana, tergantung pada soal apakah dia dalam melakukan perbuatan itu memang mempunyai kesalahan atau tidak. Apabila orang yang melakukan perbuatan pidana itu memang mempunyai kesalahan, maka tentu dia akan dipidana (Saleh, 2004: 75).

Untuk dapat dipidananya si pelaku, disyaratkan bahwa tindak pidana yang dilakukannya itu memenuhi unsur-unsur yang telah ditentukan dalam undang-undang. Selain itu, pertanggungjawaban pidana dalam hukum pidana positif dirumuskan dalam asas geen straf zonder schuld atau asas 'tiada pidana tanpa kesalahan.'

Tindakpidanajikatidakadakesalahanadalah merupakan asas pertanggungjawaban pidana. Oleh sebab itu dalam hal dipidananya seseorang yang melakukan perbuatan sebagaimana yang telah diancamkan, ini tergantung dari soal apakah dalam melakukan perbuatan ini dia mempunyai kesalahan (Moeljatno, 1993: 49). Kesalahan memiliki beberapa unsur yaitu:

a. Adanya Kemampuan bertanggung jawab pada si pelaku, dalam arti jiwa si pelaku dalam keadaan sehat dan normal;

b. Adanya hubungan batin antara si pelaku dengan perbuatannya, baik yang disengaja (dolus) maupun karena kealpaan (culpa); 
c. Tidak adanya alasan pemaaf yang dapat menghapus kesalahan (Prasetyo, 2011: 82)

Menurut doktrin tanggung jawab mutlak, dikenal adanya strict liability dan vicarious liability. Menurut doktrin strict liability (pertanggungan yang ketat), seseorang sudah dapat dipertanggungjawabkan untuk tindak pidana tertentu walaupun pada diri orang itu tidak ada kesalahan (mens rea). Sedangkan vicarious liability adalah suatu pertanggungjawaban pidana yang dibebankan kepada seseorang atas perbuatan orang lain (the legal responsibility of one person for the wrongful acts of another) (Atmasasmita, 1989: 93).

\section{Anak}

Anak adalah seseorang yang belum berusia 18 (delapan belas) tahun, termasuk anak yang masih dalam kandung (Pasal 1 butir 1 Undang-Undang Nomor 35 Tahun 2014 tentang Perubahan Atas Undang-Undang Nomor 23 Tahun 2002 tentang Perlindungan Anak). Definisi perlindungan anak adalah segala kegiatan untuk menjamin dan melindungi anak dan hak-haknya agar dapat hidup, tumbuh, berkembang, dan berpartisipasi, secara optimal sesuai dengan harkat dan martabat kemanusiaan, serta mendapat perlindungan dari kekerasan dan diskriminasi (Pasal 1 butir 2 Undang-Undang Nomor 35 Tahun 2014 tentang Perubahan Atas Undang-Undang Nomor 23 Tahun 2002 tentang Perlindungan Anak).

UNICEF dalam dokumen A/50/456 mendefinisikan pelacuran anak (child prostitution) sebagai perbuatan dengan menggunakan atau menawarkan jasa seksual anak untuk melakukan kegiatan seksual demi uang atau pertimbangan lainnya dengan seseorang atau beberapa orang. Praktek anak yang dilacurkan merupakan salah satu bentuk eksploitasi seksual komersial anak (ESKA), yaitu pemanfaatan anak untuk tujuan seksual dengan kompensasi berupa imbalan tunai/bentuk lainnya oleh pembeli jasa seksual, perantara/agen dan pihak lainnya yang memperoleh keuntungan dari kegiatan ini. Anak, dalam fenomena ESKA, pada dasarnya tidak mampu membuat keputusan untuk memilih prostitusi sebagai profesinya (Eddyono \& Ermelina, 2016: 6).

Eksploitasi seksual komersial anak (ESKA) sendiri terbagi atas:

a. Pemakaian anak perempuan dan anak laki-laki dalam kegiatan seksual yang dibayar dengan uang tunai atau dalam bentuk barang (umumnya dikenal sebagai prostitusi anak) di jalanan atau di dalam gedung, di tempattempat seperti rumah pelacuran, diskotek, panti pijat, bar, hotel, dan restoran.

b. Wisata seks anak.

c. Pembuatan, promosi, dan distribusi pornografi yang melibatkan anakanak.

d. Pemakaian anak-anak dalam pertunjukan seks (publik/swasta).

e. Penggunaan anak di dalam pertunjukan seks (di dalam publik dan privat) (ILO, 2007: 7).

\section{Teori Viktimologi}

Viktimologi, dari kata victim (korban) dan logi (ilmu pengetahuan), bahasa Latin victima (korban) dan logos (ilmu pengetahuan). Secara sederhana viktimologi/victimology artinya ilmu pengetahuan tentang korban (kejahatan). Menurut kamus Crime Dictionary yang dikutip seorang ahli yang bernama Abdussalam, bahwa yang dimaksud dengan victim adalah "Orang yang telah mendapatkan penderitaan fisik atau 
penderitaan mental, kerugian harta benda atau mengakibatkan mati atas perbuatan atau usaha pelanggaran ringan dilakukan oleh pelaku tindak pidana dan lainnya." Di sini jelas yang dimaksud "orang yang mendapat penderitaan fisik dan seterusnya" itu adalah korban dari pelanggaran atau tindak pidana (Waluyo, 2011: 9).

Secara yuridis pengertian korban termaktub dalam Undang-Undang Nomor 13 Tahun 2006 tentang Perlindungan Saksi dan Korban, yang dinyatakan bahwa korban adalah "Seseorang yang mengalami penderitaan fisik, mental dan/ atau kerugian ekonomi yang diakibatkan suatu tindak pidana" (Pasal 1, ayat (2) Undang-Undang Nomor 13 Tahun 2006 tentang Perlindungan Saksi dan Korban). Melihat rumusan tersebut, yang disebut korban adalah:

1. Setiap orang;

2. Mengalami penderitaan fisik, mental, dan/atau;

3. Kekurangan ekonomi; dan

4. Akibat tindak pidana (Waluyo, 2011: $10)$.

Manfaat dan tujuan viktimologi adalah untuk meringankan kepedihan dan penderitaan manusia di dunia. Penderitaan dalam menjadi korban jangka pendek dan panjang yang berupa kerugian fisik, mental, maupun moral, sosial, ekonomis, kerugian yang hampir sama sekali dilupakan, diabaikan oleh kontrol sosial yang melembaga, seperti penegak hukum, penuntut umum, pengadilan, petugas probation, pembinaan, permasyarakatan, dan sebagainya.

Menurut Peraturan Pemerintah Nomor 2 Tahun 2002 tentang Tata Cara Perlindungan terhadap Korban dan Saksi dalam Pelanggaran Hak Asasi Manusia yang berat, korban adalah "orang perorangan atau kelompok orang yang mengalami penderitaan sebagai akibat pelanggaran hak asasi manusia yang berat, yang memerlukan perlindungan fisik dan mental dari ancaman, teror dan kekerasan pihak maupun" (Gosita, 2004: 41).

\section{METODE}

Metode yang dipakai dalam penelitian ini adalah metode yuridis normatif. Metode penelitian hukum normatif adalah suatu prosedur penelitian ilmiah untuk menemukan kebenaran berdasarkan logika keilmuan hukum dari sisi normatifnya (Ibrahim, 2007: 57). Tipe penelitian hukum yang dilakukan adalah yuridis normatif, dengan pertimbangan bahwa titik tolak penelitian analisis berdasarkan studi kasus pada putusan pengadilan kasus aborsi yang dilakukan oleh anak korban perkosaan inces.

Adapun pendekatan-pendekatan yang digunakan di dalam penelitian ini adalah pendekatan kasus (case approach), dilakukan dengan cara melakukan telaah terhadap Putusan Nomor 5/PID.SUS-ANAK/2018/PN.MBN yang telah menjadi putusan pengadilan. Kemudian pendekatan undang-undang (statute approach) dilakukan dengan menelaah semua undangundang dan regulasi yang bersangkut paut dengan isu hukum yang sedang ditangani. Lalu pendekatan konseptual (conceptual approach) beranjak dari pandangan-pandangan dan doktrindoktrin yang berkembang di dalam ilmu hukum.

Adapun jenis dan sumber data yang digunakan dalam penelitian ini adalah data sekunder. Data sekunder menjadi data utama karena penelitian ini bersifat normatif. Data utama dalam penelitian ini adalah putusan pengadilan dan undang-undang. Selain itu juga didapat dari berbagai literatur, buku, perundang-undangan, jurnal, makalah, internet, koran, dan majalah 
yang merupakan keterangan melalui pustaka.

Analisis data yang digunakan dalam penelitian iniadalahdeskriptifkualitatif. Deskriptif adalah data yang terkumpul disusun untuk kemudian dianalisis dan hasilnya dideskripsikan/ dipaparkan secara sistematis. Sedangkan data kualitatif adalah dengan menganalisis data yang bertitik tolak pada usaha-usaha penemuan asasasas dan informasi-informasi yang bersifat ungkapan monografis dari responden, atau dengan kata lain lebih menitikberatkan pada mutu (kualitas) data, pada akhirnya akan diperoleh pemahaman yang lebih mendalam.

\section{HASIL DAN PEMBAHASAN}

Berdasarkan data dari Komisi Nasional Perempuan tahun 1998 sampai dengan 2010, perkosaan adalah jenis kekerasan seksual yang paling sering terjadi di Indonesia, yaitu sekitar 55\% dari keseluruhan kasus. Berdasarkan riset MaPPI FHUI pada tahun 2016 terhadap putusan kasus-kasus perkosaan, relasi antara pelaku dan korban kekerasan seksual, mayoritas 84,65\% adalah orang yang dikenal oleh korban, yaitu teman, pacar, tetangga, keluarga, guru, tokoh yang dituakan, dan hanya $15,35 \%$ pelaku adalah orang asing. Dalam Putusan Nomor 5/PID.SUSANAK/2018/PN.MBN, perkosaan yang dialami oleh anak korban perkosaan dilakukan oleh kakak kandungnya, dan semakin memperkuat pendapat Mosse.

Perkosaan yang dialami anak korban perkosaan adalah merupakan pelanggaran hak atas otoritas tubuhnya, hak untuk bebas daripenyiksaan, dan terjadinya kekerasan seksual merupakan indikasi jelas adanya ketidaksetaraan gender, serta dampak yang ditimbulkan jangka panjang bahkan seumur hidup. Dampak dari kekerasan seksual yang dialami korban di antaranya adalah trauma secara seksual, luka secara fisik, kehamilan tidak diinginkan, dampak psikologis, gangguan fungsi reproduksi, dan dalam beberapa kasus adanya dorongan untuk bunuh diri.

Hambatan yang dialami korban kekerasan seksual dalam mengakses keadilan di antaranya yaitu: (1) secara hukum perkosaan masih ditempatkan sebagai kejahatan terhadap kesusilaan, rumusan terkait perkosaan juga masih sempit dan terbatas; (2) aparat penegak hukum (APH) yang masih bias gender; (3) reviktimisasi dan victim blaming terhadap korban kekerasan seksual; dan (4) hukum acara dan sarana prasarana yang belum berperspektif korban (MaPPI FHUI, 2016).

Putusan hakim yang memenjarakan anak korban perkosaan, selain akan berdampak secara fisik, mental, sosial korban, apalagi korban juga masih dalam kategori anak, juga akan berdampak secara luas di mana korban-korban perkosaan lainnya akan semakin enggan untuk melaporkan kasus yang menimpanya dan memilih untuk bungkam karena tidak mendapatkan penanganan yang tepat, dan berisiko mendapatkan dampak negatif yang lebih besar dan membuat pelaku tindak kejahatan akhirnya terlepas dari jerat hukum.

Tindakan yang seharusnya diberikan kepada perempuan korban adalah dengan rehabilitasi, bukan dengan memenjarakan korban yang melakukan aborsi karena ketidaktahuannya dan rasa malu serta tekanan yang dialaminya. Hakim seharusnya dapat menggali dampak yang dialami korban karena kekerasan seksual yang dialaminya, bahwa akibat dari kekerasan seksual yang dialaminya dan reviktimisasi akan:

a. membuat korban berpikir bahwa 
mereka tidak memiliki kendali atas tubuh mereka;

b. korban harus menanggung malu bahkan mendapatkan stigma dari keluarga, masyarakat, dan lingkungan sekitarnya;

c. korban akan cenderung menyalahkan diri sendiri atas hal yang dialami;

d. korban dapat kehilangan kontrol atas tubuhnya dan mengalami perasaan sedih, trauma, kehilangan rasa percaya diri yang berujung pada depresi serta ketakutan;

e. pada korban anak akan berdampak pada adanya kekerasan lanjutan (MaPPI FHUI, 2016).

Hak korban adalah hak yang dimiliki oleh perempuan korban akibat peristiwa pidana yang dialaminya. Hak korban meliputi hak atas penanganan, perlindungan, dan pemulihan yang didapatkan, digunakan dan dinikmati oleh korban, dengan tujuan mengubah kondisi korban menjadi lebih baik, bermartabat dan sejahtera, yang berpusat pada kebutuhan dan kepentingan korban yang multi dimensi, berkelanjutaan dan partisipatif (Junianto et al., 2009: 23).

Bahwa berdasarkan KUHAP, UndangUndang Nomor 31 Tahun 2014 tentang Perubahan Atas Undang-Undang Nomor 13 Tahun 2006 tentang Perlindungan Saksi dan korban, dan Undang-Undang Nomor 23 Tahun 2004 tentang Penghapusan Kekerasan dalam Rumah Tangga, hak-hak perempuan berhadapan dengan hukum di antaranya adalah:

a. Hak memperoleh perlindungan atas keamanan pribadi, keluarga dan harta bendanya, bebas dari ancaman yang berkaitan dengan kesaksian yang akan, sedang atau telah diberikan;

b. Hak ikut serta dalam proses memilih dan menentukan bentuk perlindungan dan dukungan keamanan; c. Hak memberikan keterangan tanpa tekanan;

d. Hak mendapatkan penerjemah;

e. Hak bebas dari pertanyaan yang menjerat;

f. Hak mendapatkan informasi mengenai perkembangan kasus dan putusan pengadilan;

g. Hak untuk mengetahui dalam hal terpidana dibebaskan;

h. Hak dirahasiakan identitasnya;

i. Hak mendapatkan identitas baru;

j. Hak memperoleh penggantian biaya transportasi sesuai dengan kebutuhan;

k. Hak mendapatkan nasihat hukum;

1. Hak memperoleh bantuan biaya hidup sementara sampai batas waktu perlindungan berakhir;

m. Hak mendapatkan pendamping;

n. Hak mendapatkan restitusi;

o. Hak atas pemulihan.

Upaya perlindungan hukum bagi pelaku tindak pidana diatur dalam Pasal 50 sampai dengan Pasal 68 Undang-Undang Nomor 8 Tahun 1981 tentang Hukum Acara Pidana, mengatur perlindungan terhadap tersangka atau terdakwa untuk mendapat perlindungan dari berbagai kemungkinan pelanggaran hak asasi manusia. Undang-Undang Nomor 36 Tahun 2009 tentang Kesehatan dan Peraturan Pemerintah Nomor 61 Tahun 2014 tentang Kesehatan Reproduksi telah mengatur dan memberikan pengecualian terhadap korban perkosaan. Pasal 77A jo. Pasal 45 Undang-Undang Nomor 35 Tahun 2014 tentang Perubahan Kedua Atas Undang-Undang 
Nomor 23 Tahun 2002 tentang Perlindungan Anak mengatur ketentuan melarang setiap anak melakukan aborsi, kecuali dengan alasan dan tata cara yang dibenarkan sesuai ketentuan peraturan perundang-undangan.

Perlindungan hukum berarti melindungi hak setiap orang untuk mendapatkan perlakuan dan perlindungan yang sama oleh hukum dan undang-undang. Oleh karena itu untuk setiap pelanggaran hukum yang dituduhkan padanya serta dampak yang diderita olehnya, ia berhak pula untuk mendapat perlindungan dari hukum yang diperlukan sesuai dengan asas hukum (Susanti, 2012-2013: 301). Asas hukum yang dimaksud yaitu larangan aborsi yang diatur juga pada Pasal 75 ayat (1) Undang-Undang Kesehatan Nomor 36 Tahun 2009 tentang Kesehatan.

Adapunpengecualianyang dijelaskan dalam Pasal 75 ayat (2) Undang-Undang Kesehatan terhadap larangan melakukan aborsi diberikan hanya dalam dua kondisi. Regulasi tentang pengguguran kandungan yang disengaja (abortus provocatus) dalam KUHP diatur dalam Buku Kedua Bab XIV tentang Kejahatan Kesusilaan khususnya Pasal 299, dan Bab XIX Pasal 346 sampai dengan Pasal 349, dan digolongkan ke dalam kejahatan terhadap nyawa. Dari ketentuan Pasal 346-349 KUHP dapat diketahui, bahwa aborsi menurut konstruksi yuridis peraturan perundang-undangan di Indonesia yang terdapat dalam KUHP adalah tindakan menggugurkan atau mematikan kandungan yang dilakukan oleh seorang perempuan atau orang yang disuruh melakukan itu.

Perempuan dalam hal ini adalah perempuan hamil yang atas kehendaknya ingin menggugurkan kandungannya. Sedangkan tindakan yang menurut KUHP dapat disuruh lakukan untuk itu adalah dokter, bidan atau juru obat.

Tindakan aborsi yang diatur dalam Pasal 75 ayat (2) Undang-Undang Kesehatan itu pun hanya dapat dilakukan setelah melalui konseling dan/atau penasihatan pra tindakan dan diakhiri dengan konseling pasca tindakan yang dilakukan oleh konselor yang kompeten dan berwenang, yang dijelaskan pada Pasal 75 ayat (3) UndangUndang Kesehatan. Jadi, praktik aborsi yang bertentangan dengan peraturan perundangundangan sebagaimana disebut di atas merupakan aborsi ilegal. Sanksi pidana bagi pelaku aborsi ilegal diatur dalam Pasal 194 Undang-Undang Kesehatan yang berbunyi:

"Setiap orang yang dengan sengaja melakukan aborsi tidak sesuai dengan ketentuan sebagaimana dimaksud dalam Pasal 75 ayat (2) dipidana dengan pidana penjara paling lama 10 tahun dan denda paling banyak Rp1.000.000.000.- (satu miliar)."

Putusan Nomor 5/PID.SUS-ANAK/2018/ PN.MBN menunjukkan bahwa hakim tidak menggali fakta-fakta seperti adanya riwayat kekerasan dari pelaku, adanya relasi kuasa, ketidakberdayaan fisik dan psikis korban, serta dampak psikis yang dialami korban; bahwa hakim lalai dalam mengidentifikasikan adanya dampak psikis, serta tidak menggali adanya dampak psikis yang dialami anak korban perkosaan, karena hakim tidak berusaha menghadirkan ahli dari psikolog yang akan menilai adanya trauma atau kondisi kejiwaan korban, dan tidak menjadikan kondisi psikologis korban sebagai bahan pertimbangan.

Melihat alasan-alasan di atas dapat disimpulkan anak korban perkosaan tidak mendapatkan hak-haknya selama menjalani 
proses hukum. Padahal pemenuhan hak tersebut merupakan suatu prasyarat peradilan yang adil, tidak memihak dan bebas dari diskriminasi. Bahwa dalam memutus perkara perempuan yang berhadapan dengan hukum, hakim harus mempertimbangkan: kerugian yang dialami korban; dampak dari kasus baik secara fisik, psikis, sosial, dan ekonomi; kondisi perempuan korban/saksi; potensi bahaya yang mengancam nyawa; hasil visum et repertum dan visum et repertum psychiatricum; adanya relasi kuasa dan kondisi ketidakberdayaan korban; adanya siklus kekerasan, riwayat kekerasan; pengalaman perempuan terkait adanya kekerasan gender dan diskriminasi; dan kebutuhan untuk pemulihan (PERMA Nomor 3 Tahun 2017).

Anak Korban Perkosaan juga mengalami tekanan psikis atas ancaman yang dilakukan oleh kakak korban perkosaan sejak pertama kali perkosaan terjadi, dengan ancaman akan dipukuli atau ancaman fisik. Bahkan ancaman dan tindakan perkosaan sudah dilakukan oleh kakak kandung korban sebanyak sembilan kali sejak pertama kali perkosaan terjadi (Putusan Nomor 5/PID.SUS-ANAK/2018/PN.MBN). Dengan adanya fakta tersebut, korban tentu saja mengalami tekanan psikis untuk melaporkan adanya tindakan perkosaan yang dilakukan oleh kakak kandungnya dalam kurun waktu enam bulan sesuai dengan peraturan perundangan yang ada.

Pasal 4 huruf d PERMA Nomor 3 Tahun 2017 tentang Pedoman Mengadili Perkara Perempuan Berhadapan dengan Hukum mewajibkan hakim agar mempertimbangkan kondisi perempuan dengan mengidentifikasi fakta persidangan terkait dampak psikis yang dialami korban. Berdasarkan penjelasan sebelumnya, seharusnya alasan aborsi yang dilakukan anak korban perkosaan dapat dibenarkan menurut peraturan perundang-undangan.

Berkaitan dengan pertanggungjawaban pidana terhadap anak di bawah umur telah diatur dalam KUHP dan di luar KUHP. Pertanggungjawaban pidana anak dalam KUHP, dengan dilihatnya suatu perbuatan yang diatur di dalam undang-undang. Sebagai dasar tersebut telah didasarkan dalam asas-asas yang berkaitan dengan pertanggungjawaban pidana, yaitu berupa asas legalitas dan asas kesalahan, sebagaimana Hamzah yang mengutip pendapat Pompe dan Jonkers, memasukan juga "melawan hukum" sebagai kesalahan dalam arti luas di samping "sengaja" atau "kesalahan" (schuld) dan dapat dipertanggungjawabkan (toerekeningsvatbaarheid), atau istilah Pompe toerekenbaar (Hamzah, 2010: 112).

Dapat dinyatakan bahwa undang-undang merupakan kekuatan sebuah aturan yang telah ada, sebagai ketentuan dalam perbuatan yang dikatakan sebagai tindak pidana. Terkait dengan pertanggungjawaban secara yuridis yang diatur dalam KUHP, terdapat aturan dalam pertanggungjawaban pidana, bahwa tidak semua orang dikatakan mampu bertanggung jawab. Seseorang dikatakan tidak mampu bertanggung jawab dapat dilihat dari dua aspek, yaitu:

1) Keadaan jiwanya:

a. terganggu oleh penyakit, yang terusmenerus (temporary);

b. mengalami cacat dalam pertumbuhan (gagu, idiot, imbecile, dan sebagainya);

c. terganggu karna terkejut, hypnotism, amarah yang meluap, pengaruh 
bawah sadar, melindur, mengigau, dan sebagainya.

2) Kemampuan jiwanya:

a. tidak dapat menginsyafi hakikat tindakan yang dilakukannya;

b. Tidak dapatmenentukankehendaknya atas tindakan yang akan dilakukan; dan

c. tidak dapat mengetahui ketercelaan dari tindakan tersebut.

Aspek di atas merupakan dasar ketetapan di dalam menentukan seseorang yang melakukan suatu tindak pidana yang tidak dapat dimintai pertanggungjawaban. Dalam pengertiannya, bahwa seseorang untuk dapat dimintai pertanggungjawaban atas perbuatan yang dilakukannya, dengan kedua aspek tersebut tidak mengalami permasalahan, baik keadaan jiwanya dan kemampuan jiwanya.

\section{Berkaitan dengan persoalan} pertanggungjawaban seorang anak yang masih di bawah umur, selain menyangkut usia sebagai hal penting, seorang anak dapat dimintai pertanggungjawaban, namun kedua aspek tersebut juga merupakan tolok ukur seorang anak yang melakukan perbuatan pidana dapat dimintai pertanggungjawaban. Sedangkan dilihat dari pertanggungjawaban pidana anak di bawah umur yang terdapat di luar KUHP, dalam hal peraturan tentang perbuatan pidana yang dilakukan oleh seseorang yang belum dewasa, dalam pemberian hukuman sanksi pidana, tidak hanya dapat dilihat dalam ketentuan hukuman yang terdapat dalam KUHP sebagai hukum materil. Mengingat adanya perbedaan dalam pemberian sanksi terhadap seseorang yang belum dewasa dangan orang dewasa yang melakukan perbuatan pidana, dengan perbedaan tersebut, sehingga dalam peradilan pidana terhadap seseorang yang masih di bawah umur terdapat aturan perbuatan yang oleh undang-undang lainnya telah diatur mengenai asas "tindak pidana khusus menyampingkan tindak pidana umum (lex specialis derogat legi generali) yang telah dijelaskan dalam Pasal 103 KUHP."

Perbuataan yang oleh ketentuan perundangundangan lainnya diancam dengan pidana, kecuali jika oleh undang-undang ditentukan lain. Artinya bahwa terhadap hukuman pidana anak, telah diatur di dalam undang-undang khusus anak, beberapa di antaranya adalah UndangUndang Nomor 11 Tahun 2012 tentang Sistem Peradilan Pidana Anak, Undang-Undang Nomor 35 Tahun 2014 tentang Perubahan Kedua Atas Undang-Undang Nomor 23 Tahun 2002 tentang Perlindungan Anak, dan Undang-Undang Nomor 4 Tahun 1979 tentang Kesejahteraan Anak.

\section{Undang-Undang Nomor 11 Tahun 2012} tentang Sistem Peradilan Pidana Anak sebagai instrumen peradilan anak menyebutkan bahwa sistem peradilan pidana anak dilaksanakan berdasarkan asas, perlindungan, keadilan, nondiskriminasi, kepentingan terbaik bagi anak, penghargaan terhadap pendapat bagi anak, kelangsungan hidup dan tumbuh kembang anak, pembinaan dan pembimbingan anak proposional, perampasan kemerdekaan dan pemidanaan sebagai upaya terakhir, dan penghindaran pembalasan (Penjelasan Undang-Undang Nomor 11 Tahun 2012 tentang Sistem Peradilan Anak Pasal 2 Ketentuan Umum).

Beberapa undang-undang khusus anak serta asas-asas yang disebutkan menjadi landasan untuk mencari kebenaran dan keadilan terhadap anak, 
dengan menitikberatkan kepada hukum materil. Oleh karenanya hakim perlu memperhatikan serta mengkaji pada isi surat dakwaan jaksa penuntut umum yang akan disampaikan dalam peradilan anak, dengan memperhatikan unsur-unsur dalam pasal yang didakwakan, dan putusan yang dibuat oleh jaksa penuntut umum.

Dalam menentukan seorang anak memiliki unsur-unsur tindak pidana dan tidak, perlu melihat dari beberapa aspek, yaitu: (1) dilihat dari kemampuan bertanggung jawab anak yang melakukan pidana, artinya bahwa apakah anak tersebut sudah memenuhi ketentuan usia anak yang telah diatur dalam Undang-Undang Peradilan Anak; (2) unsur pertanggungjawaban pidana, artinya lebih mengacu pada unsur kesalahan yang menjadi unsur penting dalam tindak pidana, untuk menentukan apakah anak tersebut dapat dipidana atau tidak; dan (3) pembuktian yang didasarkan pada bukti-bukti yang akan dibuktikan dalam proses peradilan anak.

Dalam kasus ini, anak korban perkosaan/anak yang berhadapan dengan hukum $(\mathrm{ABH})$ tersebut dituntut melakukan perbuatan aborsi sebagaimana diatur di dalam Pasal 77A jo. Pasal 45 Undang-Undang Nomor 35 Tahun 2014 tentang Perubahan Kedua Atas Undang-Undang Nomor 23 Tahun 2002 tentang Perlindungan Anak jo. Pasal 55 ayat (1) ke-1 KUHP.

Unsur kesalahan yang dipenuhi oleh terdakwa yakni:

1. Dengan sengaja (unsur kesalahan);

2. Melakukan aborsi;

3. Terhadap anak yang masih dalam kandungan;
4. Dengan alasan dan tata cara yang tidak dibenarkan oleh ketentuan peraturan perundang-undangan.

Dalam proses persidangan, $\mathrm{ABH}$ menyatakan perutnya mengalami kesakitan kepada saksi AD tanggal 22 Mei 2018. Kemudian saksi $\mathrm{AD}$ (ibu dari $\mathrm{ABH}$ ) memberikan minyak angin dan membuatkan sari pati kunyit dicampur dengan garam kepada $\mathrm{ABH}$, ketika $\mathrm{ABH}$ tersebut masih mengalami kesakitan di perutnya. Pada pukul 18.00 WIB sore harinya, ABH menguruturut perutnya, kemudian bayi $\mathrm{ABH}$ tersebut lahir dan masih dalam kondisi bernafas tetapi tidak menangis. Kemudian, ABH memotong tali pusar bayi tersebut dan setelahnya anak bayi tersebut tidak bernyawa lagi. ABH kemudian membalut bayi tersebut dengan jilbab warna putih dan taplak meja warna coklat kemudian diletakkan di bawah kasur. Keesokan harinya, ABH membawa mayat bayi tersebut ke kebun sawit di dekat rumah untuk dikubur setelah saksi AD pergi bekerja.

Hakim menyatakan dalam putusannya bahwa majelis hakim tidak menemukan hal-hal yang dapat menghapuskan pertanggungjawaban pidana, baik sebagai alasan pembenar dan atau alasan pemaaf. Tidak adanya alasan pemaaf dikarenakan $\mathrm{ABH}$ tidak ada kecacatan dalam dirinya baik karena gangguan psikis maupun fisik. Perbuatan terlarang yang dilakukan terdakwa dilakukan secara sukarela.

\section{KESIMPULAN}

Dari uraian permasalahan di atas dapat ditarik kesimpulan, bahwa putusan hakim yang memidana anak korban perkosaan inses yang melakukan aborsi belum mempertimbangkan hak-hak anak sebagai korban. Hakim tidak menggali fakta-fakta seperti adanya riwayat 
kekerasan dari pelaku, adanya relasi kuasa, ketidakberdayaan fisik dan psikis korban, serta dampak psikis yang dialami korban. Hakim lalai dalam mengidentifikasikan adanya dampak psikis serta tidak menggali adanya dampak psikis yang dialami anak korban perkosaan, karena hakim tidak berusaha menghadirkan psikolog yang akan menilai adanya trauma atau kondisi kejiwaan korban, dan tidak menjadikan kondisi psikologis korban sebagai bahan pertimbangan.

Hakim dalam memutus perkara perempuan yang berhadapan dengan hukum tidak mempertimbangkan kerugian yang dialami korban; dampak dari kasus baik secara fisik, psikis, sosial dan ekonomi; kondisi perempuan korban/saksi; potensi bahaya yang mengancam nyawa; hasil visum et repertum dan visum et repertum psychiatricum; adanya relasi kuasa dan kondisi ketidakberdayaan korban; adanya siklus kekerasan, riwayat kekerasan; pengalaman perempuan terkait adanya kekerasan gender dan diskriminasi; dan kebutuhan untuk pemulihan.

Dalam memutus perkara, pertimbangan putusan pidana hakim adalah terdakwa telah memenuhi unsur-unsur perbuatan pidana dan unsur-unsur kesalahan serta tidak adanya alasan penghapus pidana, sehingga terdakwa dianggap mampu bertanggung jawab secara pidana dan selanjutnya dapat dipidana.

\section{SARAN}

Adapun saran yang bisa diberikan oleh penulis adalah:

1. Dalam memutus perkara terutama perkara yang berhubungan dengan kekerasan seksual yang dialami oleh perempuan terutama anak, hakim harus menggali lebih jauh lagi dari berbagai aspek, tidak saja memutus berdasarkan bunyi undang-undang. Pidana sama sekali tidak memberikan pemulihan terhadap korban, malah membuat korban mengalami penderitaan lebih dalam.

2. Pencegahan dini tentang kekerasan seksual terutama perkosaan yang dilakukan oleh anak terhadap anak secara inses melalui kerjasama di berbagai bidang.

3. Meningkatkan peran keluarga terutama orang tua terhadap pergaulan dan perilaku anak di dalam maupun di luar rumah.

\section{DAFTAR ACUAN}

Atmasasmita, R. (1989). Asas-asas perbandingan hukum pidana. Jakarta: Yayasan Lembaga Bantuan Hukum Indonesia.

CNN Indonesia. (2018). Komnas Perempuan sebut 1.210 kasus inses terjadi pada 2017. Diakses dari http://m.cnnindonesia.com.

Eddyono, S.W., \& Ermelina, S. (2016). Penanganan kasus eksploitasi seksual komersial anak (ESKA) di Indonesia belajar dari pengalaman penanganan perkara kasus-kasus ESKA di Indonesia. Jakarta: Institute for Criminal Justice Reform (ICJR).

Gosita, A. (2004). Masalah korban kejahatan. Jakarta: PT Bhuana Ilmu Populer.

Hamzah, A. (2010). Asas-asas hukum pidana. Jakarta: Rineka Cipta.

Ibrahim, J. (2007). Teori \& metodologi penelitian normatif. Malang: Bayumedia

ILO. (2007). Commercial sexual exploitation of 
children. Diakses dari http://ilo.org/ipec/areas/ CSEC/lang--en/index.htm.

Junianto, D. et al. (2009). Perlindungan terhadap saksi \& korban. Jakarta: Komnas Perempuan

MaPPI FHUI. (2016). Booklet kekerasan seksual di Indonesia: Data, fakta \& realita. Jakarta: Masyarakat Pemantau Peradilan Indonesia Fakultas Hukum Universitas Indonesia.

Moeljatno. (1993). Perbuatan pidana \& pertanggungjawaban dalam hukum pidana. Jakarta: Bina Aksara.

Noviana, I. (2015, Januari-April). Kekerasan seksual terhadap anak: Dampak \& penanganannya (Child sexual abuse: Impact \& handling). Sosio Informa, 1(1), 13-28.

Prasetyo, T. (2011). Hukum pidana. Edisi Revisi. Jakarta: PT Raja Grafindo Persada.

Ranoemihardja, R.A. (1991). Ilmu kedokteran kehakiman (Forensic science). Bandung: Tarsito.

Sahetapy, J.E. (1987). Viktimologi sebuah bunga rampai. Cet. I. Jakarta: Pustaka Sinar Harapan.

Saleh, R. (2004). Perbuatan pidana \& pertanggungjawaban pidana; Dua pengertian dasar dalam hukum pidana. Jakarta: Aksara Baru.

Susanti, Y. (2012, September - 2013, Februari). Perlindungan hukum bagi pelaku tindak pidana aborsi (Abortus provocatus) korban perkosaan. Jurnal Ilmu Hukum Syiar Hukum, XIV(2), 299311.

Triwibowo, C. (2014). Etika \& hukum kesehatan. Yogyakarta: Nuha Medika.

Waluyo, B. (2011). Viktimologi perlindungan korban \& saksi. Jakarta: Sinar Grafika 